\title{
Deus, felicidade plena do ser humano $O$ conceito de Deus na teologia de Andrés Torres Queiruga
}

\author{
Orientador: Mario de França Miranda \\ Mestrando: Ronaldo Silveira Motta \\ Área de Concentração: Teologia Sistemático-Pastoral \\ Linha de Pesquisa: Religião e Modernidade
}

O presente estudo procura refletir a problemática da relação ser humano e Deus no pensamento de Wolfhart Pannenberg. Para a elaboração do trabalho foram consideradas duas temáticas de grande relevância no autor mencionado: a antropologia e a história. A primeira parte se encarrega em apresentar os fundamentos antropológicos da dimensão religiosa. Para isso foi importante compreender o conceito de pessoa, de sujeito e de liberdade em nosso autor. Em Pannenberg, o tema da abertura caracteriza uma antropologia que não se fecha diante do puro imanente, mas se coloca frente ao infinito mistério de Deus. O ser humano é aquele que transcende a sua finitude e se abre ao infinito. A noção de imagem e semelhança de Deus oferece bases para uma leitura teológica da antropologia. A segunda parte trabalha o tema da revelação como história no contexto judaico - cristão. Conforme o teólogo alemão a revelação se dá de forma indireta através dos acontecimentos históricos. Nesse sentido a primeira parte se harmoniza com a segunda, pois somente se pode falar de história se consideramos o ser humano como seu protagonista. É na história humana que Deus se revela como criador, libertador e salvador da humanidade. O ápice da revelação se dá em Jesus Cristo, pois nele ela chega ao seu ponto final. Jesus já é de forma proléptica o que acontecerá com todo ser humano. A sua ressurreição antecipa a esperança futura reservada a cada pessoa. Em conformidade com o que foi afirmado, a escatologia se faz muito importante para o teólogo luterano. É nela que acontecerá o desfecho final da história humana, chamada por ele de fim da história. Jesus Cristo é o centro unificador desse futuro, em que haverá uma perfeita harmonia entre passado, presente e futuro no presente eterno de Deus. A realização final da pessoa será a eterna participação do amor divino, da trindade. Amor já manifestado pelo Pai desde o início da criação.

Palavras-chave: Imagem de Deus; Modernidade; Experiência de Abba; Realização Existencial. 